\title{
Quality Parameters, Volatile Composition, and Sensory Profiles of Highly Endangered Spanish Citrus Fruits
}

\author{
Marina Cano-Lamadrid (DD, ${ }^{1}$ Leontina Lipan, ${ }^{1}$ Francisca Hernández, ${ }^{2}$ Juan José Martínez, \\ Pilar Legua, ${ }^{2}$ Ángel A. Carbonell-Barrachina ${ }^{\circ},{ }^{1}$ and Pablo Melgarejo ${ }^{2}$ \\ ${ }^{1}$ Grupo Calidad y Seguridad Alimentaria (CSA), Departamento de Tecnología Agroalimentaria, Escuela Politécnica Superior de \\ Orihuela (EPSO), Universidad Miguel Hernández de Elche (UMH), Ctra. de Beniel, Km 3.2, Orihuela, 03312 Alicante, Spain \\ ${ }^{2}$ Departamento de Producción Vegetal, Escuela Politécnica Superior de Orihuela (EPSO), Universidad Miguel Hernández de Elche \\ (UMH), Ctra. de Beniel, Km 3.2, Orihuela, 03312 Alicante, Spain
}

Correspondence should be addressed to Marina Cano-Lamadrid; marina.cano.umh@gmail.com

Received 17 October 2017; Accepted 15 February 2018; Published 26 March 2018

Academic Editor: Eduardo Puértolas

Copyright (C) 2018 Marina Cano-Lamadrid et al. This is an open access article distributed under the Creative Commons Attribution License, which permits unrestricted use, distribution, and reproduction in any medium, provided the original work is properly cited.

There is very little information available on the chemical composition and the quality attributes of the citrus species studied which are truly endangered in Spain. None of the fruits studied is available for commercial purposes, which is the main interest and novelty of this study. The aim of this work was to fully describe the morphology, volatile composition, and sensory profile of traditional citrus fruits: sour lime (SoLi), sweet lime (SwLi), and sweet lemon (SwLe), to have the information to convince farmers and growers to cultivate these fruits again. The predominant sugar was fructose while citric acid prevails in SoLi and SwLe. Regarding volatiles compounds, monoterpenes, monoterpenoids, and esters predominated in the juices, and these three families plus sesquiterpenes in the peels. The juice of SoLi presented the highest content of esters (14.8\%), SwLi juice presented similar values of both monoterpenes and monoterpenoids (46.1 and 46.0\%, resp.), and SwLe juice had the highest content of monoterpenes (72.2\%). The results demonstrated the high potential of these citrus materials for the agrofood industry. Therefore, it will be possible to recover these vegetal materials at risk of disappearing for potential uses by the food industry and simultaneously help maintaining the biodiversity.

\section{Introduction}

Botanically, citrus is part of the family Rutaceae, subfamily Aurantioideae, containing six closely related genera: Citrus, Fortunella, Poncitrus, Microcitrus, Eremocitrus, and Clymenia. According to the classification by Swingle, lemons and limes belong to two species: Citrus limon (L.) Burm. and Citrus aurantifolia (Christm.) [1]. Conversely, in the Tanaka system, they are divided into several species characterized by the botanical variability [2]. The official statistics considered only one group for the production of lemons and limes, with the production of limes being much lower than that of lemons in the European Union, including Spain. In 2013, Spain was the third world producer of lemons-limes, after India and Mexico, with a production of $715300 \mathrm{t}$ [3]. As the botanical complexity of the Citrus genus (most of the fruits are hybrids), the identification of the species called "limes" in different regions of the world is very difficult. Limes are classified in three major groups: the sour or bitter one, the sweet one, and the tangerine one.

The pair lemon-lime is one of the most important fruits in tropical and subtropical regions. Due to the distinctive aromas and tastes, citrus fruits are considered as one of the most commonly consumed beverages worldwide [4]. One of the key and specific characteristics of citrus fruit quality is the aroma of both the edible juice and the peel, which is not always edible but has a fantastic aroma. Furthermore, the aroma of citrus juices is a complex combination of several aromatic compounds, including esters, aldehydes, alcohols, ketones, and hydrocarbons [5]. There are many flavorings of commercial value which belong to the Citrus genus and there has been extensively researched to determine their 
aroma-active compounds and to develop methods to evaluate product quality [6].

On the other hand, lime and lemon juice is less economic value that its peel, so it is important to know the composition of the peel of these fruits. The samples under study have traditionally been used for human consumption (sweet lime and sweet lemon) and to obtain rootstock (sweet and sours lime trees) for other citrus fruits, especially lemon and sweet orange, providing good productivity and fruit quality. Although the fruits of traditional varieties of lime consumption in Spain have been used for centuries (such as seasonings and flavoring materials and especially for some cooked foods and vegetable salads, as an acidulant, lemonade and cocktails), there is little information available on their chemical composition and their quality attributes [7]. The lack of knowledge about these plant materials puts at risk their disappearance.

The aim of this work was to fully characterize the sensory profile and the volatile aroma composition of juice and peel of traditional citrus fruits: sour lime, sweet lime, and sweet lemon, to increase the knowledge of these potential vegetal materials at risk of disappearing. The analyses were completed including morphological and instrumental quality parameters: (i) morphological and physicochemical: weight, size, and CIE $L * a * b *$ coordinates; (ii) instrumental: content of organic acids and sugars.

\section{Experimental}

2.1. Plant Material. Fruits of three endangered citrus trees (Ojós 1 sour lime, SoLi; Ojós 1 sweet lime, SwLi; Ojós 1 sweet lemon, SwLe) were collected in private orchards in Ojós ( $38^{\circ} 4^{\prime} 52.6^{\prime \prime} \mathrm{N}, 1^{\circ} 21^{\prime} 11^{\prime \prime} \mathrm{W} 120 \mathrm{~m}$ above sea level) Murcia, southeastern Spain. These citrus species are truly endangered in Spain, and most farmers believed that they were completely disappeared; however, few trees were found in this particular area and specifically in private orchards. None of these three fruits is available for commercial purposes, which is the main interest and novelty of this study. The identified trees are of high importance to allow the survival of this germplasm. These citrus fruits have been historically used for the household consumption, as baking flavoring (the citrus flavor is of high importance in the Mediterranean cuisine, including the Spanish one).

These citrus trees have survived many pests and diseases that have affected the Spanish citrus during the last centuries. The region of the "Valle de Ricote," where these specimens were located, is one of the oldest regions in Spain cultivating citrus trees.

For each fruit, 30 fruits from three trees (ten fruits per tree) were hand-harvested at physiological maturity ( $>20 \%$ of juice) to ensure their best flavor and color and immediately transported under ventilated conditions to the laboratory. Contrary to what happens with other citrus fruits, such as orange and mandarins, the maturity index [total soluble solids, TSS ( ${ }^{\circ}$ Brix): titratable acidity, TA ( $g$ citric acid per $100 \mathrm{~mL}$ )] is not the parameter used to decide proper harvest time; in lemons, the total juice content (minimum of $20 \%$ in Europe countries) is widely used as harvest indicator in lemons and limes.

2.2. Physical and Chemical Determinations. The following physical fruit characteristics were studied: fruit weight, $F_{W}$ (g); calyx length, $C_{l}(\mathrm{~mm})$; fruit total length, $F_{l}$ (mm); fruit thickness or equatorial diameter, $F_{t}(\mathrm{~mm})$; and, endocarp thickness, $E_{t}(\mathrm{~mm})$. The fruit weight was measured with a Sartorius scale model BL-600 (Sartorius, Barcelona, Spain), with an accuracy of $0.1 \mathrm{~g}$; all other physical parameters were measured with an electronic digital slide gauge (Mitutoyo, Kawasaki, Japan), with $0.01 \mathrm{~mm}$ accuracy. All physical parameters were run in 50 replications.

Total soluble solids, TSS ( ${ }^{\circ}$ Brix), were determined with the juice obtained from each sample with an Atago N1 digital refractometer (Atago Co., Ltd., Tokyo, Japan) at $20^{\circ} \mathrm{C}$. Total titratable acidity, TA (g citric acid $\mathrm{L}^{-1}$ ), was also determined by automatic titration ( 877 Titrino plus, Metrohm, Herisau, Switzerland) with $0.1 \mathrm{~N} \mathrm{NaOH}$ up to $\mathrm{pH} 8.1$, using $1 \mathrm{~mL}$ diluted juice in $25 \mathrm{~mL}$ distilled water. The CIE $L * a * b *$ color space was determined using in a Minolta CM-2002 spectrophotometer, with a liquid accessory CR-A70. All these analyses were run in 10 replications.

2.3. Organic Acids and Sugars. Organic acids and sugars profile were quantified according to Carbonell-Barrachina et al. [13]. The juices were manually prepared by squeezing the fruits, cut in halves, diluting them with ultra-high-purity deionized water $(1: 10)$, and centrifuging at $1500 \times \mathrm{g}$ for $20 \mathrm{~min}$ (Sigma 3-18 K; Sigma, Osterode am Harz, Germany). Then, $1 \mathrm{~mL}$ of supernatant was filtered through a $0.45 \mu \mathrm{m}$ Millipore filter, and $10 \mu \mathrm{L}$ was injected into a Series 1100 HewlettPackard high-performance liquid chromatograph (HPLC). A column Supelcogel ${ }^{\mathrm{TM}} \mathrm{C}-610 \mathrm{H}(30 \mathrm{~cm} \times 7.8 \mathrm{~mm})$ and a precolumn (Supelguard $5 \mathrm{~cm} \times 4.6 \mathrm{~mm}$; Supelco, Bellefonte, PA) were used for the analyses of both organic acids and sugars. The elution buffer consisted of $0.1 \%$ phosphoric acid. Organic acid absorbance was measured at $210 \mathrm{~nm}$ using a diode-array detector (DAD), while sugars were detected using a refractive index detector (RID). Standards of organic acids (citric, malic, and ascorbic) and sugars (glucose and fructose) were obtained from Sigma (St. Louis, MO) and calibration curves, with a concentration range between 1 and $10 \mathrm{~g} \mathrm{~L}^{-1}$, were used for the quantification of both organic acids and sugars, and showed good linearity $\left(R^{2} \geq 0.999\right)$. Analyses were run in triplicate and results were expressed as mean \pm standard error, in $\mathrm{g} 100 \mathrm{~mL}^{-1}$.

2.4. Volatile Compounds. Headspace solid phase microextraction (HS-SPME) was the method selected to study the volatile composition of the samples under analysis [14, 15]. After several preliminary tests to optimize the extraction system for both juice and peel, (i) $5 \mathrm{~mL}$ of each sample juice $+10 \mathrm{~mL}$ ultrapure water or (ii) $2 \mathrm{~g}$ of each sample peel $+13 \mathrm{~mL}$ ultrapure water was placed into $50 \mathrm{~mL}$ vials with polypropylene caps and PTFE/silicone septa. A magnetic stirring bar was added, together with $\mathrm{NaCl}(15 \%)$, and the vial was placed in a water bath with controlled temperature and automatic stirring. The vials were equilibrated during $15 \mathrm{~min}$ 
at $40^{\circ} \mathrm{C}$ in a water bath (to simulate the mouth temperature during the chewing process), and after this equilibration time, a $50 / 30 \mu \mathrm{m}$ DVB/CAR/PDMS fiber was exposed to the sample headspace for $50 \mathrm{~min}$ at $40^{\circ} \mathrm{C}$. This type of fiber was chosen for its high capacity of trapping fruits volatile compounds $[16,17]$. After sampling, desorption of the volatile compounds from the fiber coating was carried out in the injection port of the GC-MS during $3 \mathrm{~min}$.

The identification of the volatile compounds was performed on a gas chromatograph (GC-MS), Shimadzu GC17A (Shimadzu Corporation, Kyoto, Japan), coupled with a Shimadzu mass spectrometer detector GC-MS QP-5050A. The GC-MS system was equipped with a TRACSIL Meta X5 column, 95\% dimethylpolysiloxane, and 5\% diphenylpolysiloxane (Teknokroma S. Co. Ltd., Barcelona, Spain; 30 m $\times 0.25 \mathrm{~mm}$ i.d., $0.25 \mu \mathrm{m}$ film thickness). Analyses were carried out using helium as carrier gas at a flow rate of $6 \mathrm{~mL} \mathrm{~min}^{-1}$ in a split ratio of 6 and a program: (a) initial temperature $80^{\circ} \mathrm{C}$; (b) rate of $3.0^{\circ} \mathrm{C} \mathrm{min}^{-1}$ to $210^{\circ} \mathrm{C}$ and hold for $1 \mathrm{~min}$; (c) rate of $25^{\circ} \mathrm{C} \mathrm{min}^{-1}$ from 210 to $300^{\circ} \mathrm{C}$ and hold for $3 \mathrm{~min}$. Injector and detector temperatures were held at 230 and $300^{\circ} \mathrm{C}$, respectively.

All compounds reported in this study were identified by 3 simultaneous methods: (1) retention indices, (2) GC-MS retention times (authentic chemicals), and (3) mass spectra (authentic chemicals and Wiley spectral library collection). No tentatively identified compounds have been included in this study. The volatile composition analysis was run in triplicate and results were expressed as percentage of the total area represented by each one of the volatile compounds.

The relative abundance of the volatile compounds (\%) was performed on a gas chromatograph, Shimadzu 2010, with a flame ionization detector (FID). The column and chromatographic conditions were those previously reported for the GC-MS analysis. The injector temperature was $200^{\circ} \mathrm{C}$ and nitrogen was used as carrier gas $\left(1 \mathrm{~mL} \mathrm{~min}^{-1}\right)$. The relative abundance was obtained from electronic integration measurements using flame ionization detection (FID). Pentanal was used as internal standard and the areas from all compounds were normalized using its area; this compound was chosen after checking that it was not present in the volatile profiles of the samples under study.

2.5. Sensory Evaluation with Trained Panel. Eight trained panelists (aged 30 to 55 years; 4 females and 4 male) with more than $500 \mathrm{~h}$ of training in sensory testing from the department of Agrofood Technology (UMH) participated in this study. The panel was selected and trained following the ISO standard 8586-1 and has more than 10 years of experience; it is specialized in descriptive sensory evaluation of fruits and vegetables and has a wide expertise in studying the effects of drying on different matrixes $[18,19]$. To begin this specific study, panelists received further orientation during 2 sessions of 90 min on sensory evaluation of both juice (flavor) and peel (odor: perception of volatile compounds with the food outside the mouth) of citrus fruits.

The study was conducted in a normalized tasting room of $\mathrm{UMH}\left(21 \pm 2^{\circ} \mathrm{C}\right.$ and $55 \pm 5 \%$ relative humidity $)$ with 15 normalized sensory cabins. Samples were randomly served into odor-free, disposable $90 \mathrm{~mL}$ covered plastic cups, at room temperature, and coded using 3-digit numbers. Unsalted crackers and distillated water were provided to panelists to clean their palates between samples.

The panel evaluated only the following attributes: (i) juice (flavor): sourness, bitterness, sweetness, astringency, citric, green, and floral notes, and aftertaste; (ii) peel (odor): citric, green, and floral. The description of lexicon and the reference products used are shown in Table 6 [12].

The panel used a numerical scale $(0-10)$ for quantifying the intensity of the attributes, where 0 represents none and 10 extremely strong, with 0.5 increments. This scale is widely used by Spanish panelists because it is intuitive and very easy to understand; in addition, it is broad enough to cover the full range of the intensity of the sensory attributes and has enough discrete points to differentiate the small differences in intensity among samples [8]. An evaluation session $(1.5 \mathrm{~h}$ ) was carried out, where each panelist described the appearance, odor, and flavor attributes in all samples. This scale is the most logical and easy-to-use by Spanish panelists [9].

2.6. Statistical Analysis. Data was subjected to analysis of variance (ANOVA) and later to Tukey's multiple-range test to compare the means. Differences were considered statistically significant at $p<0.05$. All statistical analyses were performed using StatGraphics Plus 5.0 software (Manugistics, Inc., Rockville, MD).

\section{Results and Discussion}

3.1. Morphological and Physicochemical Parameters. Table 1 shows the results of morphological and physicochemical parameters of samples. It can be observed that sweet lime (SwLi) had the lowest weight, $F_{w}(p<0.001), 83 \mathrm{~g}$, followed by sour lime (SoLi), $153 \mathrm{~g}$, with sweet lemon (SwLe) presenting the highest weight, $199 \mathrm{~g}$. Citrus fruits presented significant differences in their sizes, with the ratio $F_{l}$ (length) $/ F_{t}$ (thickness) taking values of $0.82,0.85$, and 1.38, in SoLi, SwLi, and SwLe, respectively; these values meant that both types of limes are more rounded than the lemon (SwLe). The highest value of rind thickness, $E_{t}, 6.1 \mathrm{~mm}$, was SwLe $(p<0.05)$, while SwLi and SoLi had similar values, 4.2 and $4.3 \mathrm{~mm}$.

As for physicochemical properties, the sweet samples (SwLi and SwLe) presented statistically equivalent values of $\mathrm{pH}$ (7.7 and 6.9, resp.), while the sour one (SoLi) had the lowest one, 3.0. On the contrary, the highest value of titratable acidity, TA, was found in the SoLi (57.2), which was significantly higher $(p<0.001)$ than the values of the

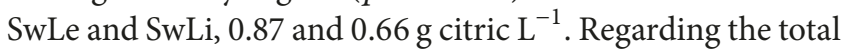
soluble solids, TTS, the results showed higher values in SwLe and SoLi (8.2 and 8.1, resp.) as compared to SwLi (6.6).

Finally, in the case of external peel CIE $L * a * b *$ coordinates were significantly different among samples $(p<$ $0.001)$. The highest values of lightness $(L *)$ and blue-yellow coordinate, $b *$, were found in SwLe, while the highest green external intensity was found in SwLi. On the other hand, it is noteworthy that the color parameters among all samples 
TABLE 1: Morphological and physicochemical parameters of endangered Spanish lime and lemon samples.

\begin{tabular}{|c|c|c|c|c|}
\hline Parameter $^{\dagger}$ & $\mathrm{ANOVA}^{\ddagger}$ & Sour lime & Sweet lime & Sweet lemon \\
\hline$F_{w}(\mathrm{~g})$ : fruit weight & $* * *$ & $153 b^{9}$ & $83 \mathrm{c}$ & $199 \mathrm{a}$ \\
\hline$C_{l}(\mathrm{~mm}):$ calyx length & $* * *$ & $3.7 \mathrm{~b}$ & $4.8 \mathrm{~b}$ & $14.4 \mathrm{a}$ \\
\hline$F_{l}(\mathrm{~mm})$ : fruit total length & $* * *$ & $58.5 \mathrm{~b}$ & $49.5 \mathrm{c}$ & $96.4 \mathrm{a}$ \\
\hline$F_{t}(\mathrm{~mm}):$ fruit thickness & $* * *$ & $71.7 \mathrm{a}$ & $58.3 \mathrm{~b}$ & $70.2 \mathrm{a}$ \\
\hline Length: thickness $\left(F_{l}: F_{t}\right)$ & $* * *$ & $0.82 \mathrm{~b}$ & $0.85 \mathrm{~b}$ & $1.38 \mathrm{a}$ \\
\hline$E_{t}(\mathrm{~mm}):$ endocarp thickness & $* * *$ & $4.2 \mathrm{~b}$ & $4.3 \mathrm{~b}$ & $6.1 \mathrm{a}$ \\
\hline $\mathrm{pH}$ & $* * *$ & $3.0 \mathrm{~b}$ & $7.7 \mathrm{a}$ & $6.9 \mathrm{a}$ \\
\hline TSS $\left({ }^{\circ}\right.$ Brix $)$ & $* * *$ & $8.1 \mathrm{a}$ & $6.6 \mathrm{~b}$ & $8.2 \mathrm{a}$ \\
\hline TA $\left(\right.$ g citric $\left.^{-1}\right)$ & $* * *$ & $57.2 \mathrm{a}$ & $0.66 \mathrm{~b}$ & $0.87 \mathrm{~b}$ \\
\hline \multicolumn{5}{|l|}{ Peel color } \\
\hline$L *$ & $* * *$ & $70.25 \mathrm{~b}$ & $70.37 \mathrm{~b}$ & $75.73 \mathrm{a}$ \\
\hline$a *$ & $* * *$ & $11.73 \mathrm{a}$ & $4.26 \mathrm{c}$ & $6.05 \mathrm{~b}$ \\
\hline$b *$ & $* * *$ & $50.42 \mathrm{~b}$ & $49.79 \mathrm{~b}$ & $53.57 \mathrm{a}$ \\
\hline \multicolumn{5}{|l|}{ Juice color } \\
\hline$L *$ & NS & $45.13 \mathrm{a}$ & $46.09 \mathrm{a}$ & $45.64 \mathrm{a}$ \\
\hline$a *$ & NS & $-0.65 \mathrm{a}$ & $-1.33 \mathrm{a}$ & $-1.00 \mathrm{a}$ \\
\hline$b *$ & NS & $-2.13 \mathrm{a}$ & $-1.77 \mathrm{a}$ & $-1.25 \mathrm{a}$ \\
\hline
\end{tabular}

${ }^{\dagger}$ The number of replications for the analysis of weight, size $\left(C_{L}, F_{l}, F_{T}\right.$, and $\left.E_{t}\right), \mathrm{pH}, \mathrm{TSS}$, and TA was 50,50,10, 10, and 10, respectively; ${ }^{\ddagger} \mathrm{NS}=$ not significant at $p<0.05 ;{ }^{* * *}$ significant at $p<0.001$, respectively; ' values followed by the same letter, within the same row, were not significantly different $(p<0.05)$, according to Tukey's least significant difference test.

TABLE 2: Concentrations of organic acids and sugars in endangered Spanish lime and lemon samples.

\begin{tabular}{|c|c|c|c|c|}
\hline Organic acids & $\mathrm{ANOVA}^{\dagger}$ & Sour lime & $\begin{array}{c}\text { Sweet lime } \\
\text { Concentration }\left(\mathrm{g} 100 \mathrm{~mL}^{-1}\right)\end{array}$ & Sweet lemon \\
\hline Citric acid & $* * *$ & $5.64 \mathrm{a}^{\ddagger}$ & $\mathrm{nd}^{9} \mathrm{c}$ & $1.35 \mathrm{~b}$ \\
\hline Malic acid & $* * *$ & $\mathrm{Nd}$ & $0.28 \mathrm{a}$ & $0.31 \mathrm{a}$ \\
\hline Ascorbic acid & NS & 0.01 & 0.02 & 0.03 \\
\hline Sugars & ANOVA & Sour lime & $\begin{array}{l}\text { Sweet lime } \\
\text { Concentration }\left(\mathrm{g} 100 \mathrm{~mL}^{-1}\right)\end{array}$ & Sweet lemon \\
\hline Glucose & $* * *$ & $\mathrm{Nd}$ & $1.61 \mathrm{a}$ & $1.22 \mathrm{a}$ \\
\hline Fructose & $* * *$ & $\mathrm{Nd}$ & $2.86 \mathrm{a}$ & $2.04 \mathrm{a}$ \\
\hline
\end{tabular}

${ }^{\dagger} \mathrm{NS}=$ not significant at $p<0.05 ;{ }^{* * *}$ significant at $p<0.05,0.01$, and 0.001 , respectively; ${ }^{\ddagger}$ values (mean of 3 replications) followed by the same letter, within the same row, were not significantly different $(p<0.05)$, according to Tukey's least significant difference test; ' $n d=$ below LOQ (limit of quantification).

juices were not significantly different $(p>0.05)$. This was interesting for manufactures due to the fact that typical color of lemon was maintained.

3.2. Organic Acids and Sugars. Only three organic acids (citric, malic, and ascorbic acids) and two sugars (glucose and fructose) were found in the citrus fruits under analysis (Table 2). These results agreed with Ting and Rouseff [10], because they stated that sucrose was only present in lemons and limes in trace contents. The citric acid predominated in SoLi and SwLe (5.64 and $1.35 \mathrm{~g} 100 \mathrm{~mL}^{-1}$, resp.). The organic acid profile of the sweet lemon was more complex than that of the other fruits as presented measurable amounts of all three compounds, while those of SoLi and SwLi were reduced basically to only one compound. The predominant sugar was fructose although no sugar was detected at measurable levels in the SoLi.
3.3. Volatile Compounds. A total of 64 different compounds have been identified in the peel and juice of the citrus fruits under study, with 51 and 50 compounds belonging to the juice and peel of the citrus fruits, respectively (Tables 3-5). Table 3 shows the retention indexes used for the identification of the compounds [11], together with other parameters and the main sensory descriptors of each of the volatiles [20-22]. To make the discussion of this section easier to follow, the volatile compounds have been grouped in eight chemical families: (i) monoterpenes (14 compounds), (ii) monoterpenoids (13), (iii) aldehydes (13), (iv) sesquiterpenes (11), (v) esters (9), (vi) alcohols and ketones (2), (vii) lineal hydrocarbons (1), and (viii) phenol derivatives (1). In general, Figure 1 shows the comparative importance of each of these families in the juice (Figure 1(a)) and peel (Figure 1(b)) of these fruits and clearly shows the predominance of monoterpenes, monoterpenoids, and esters in the juices and these 


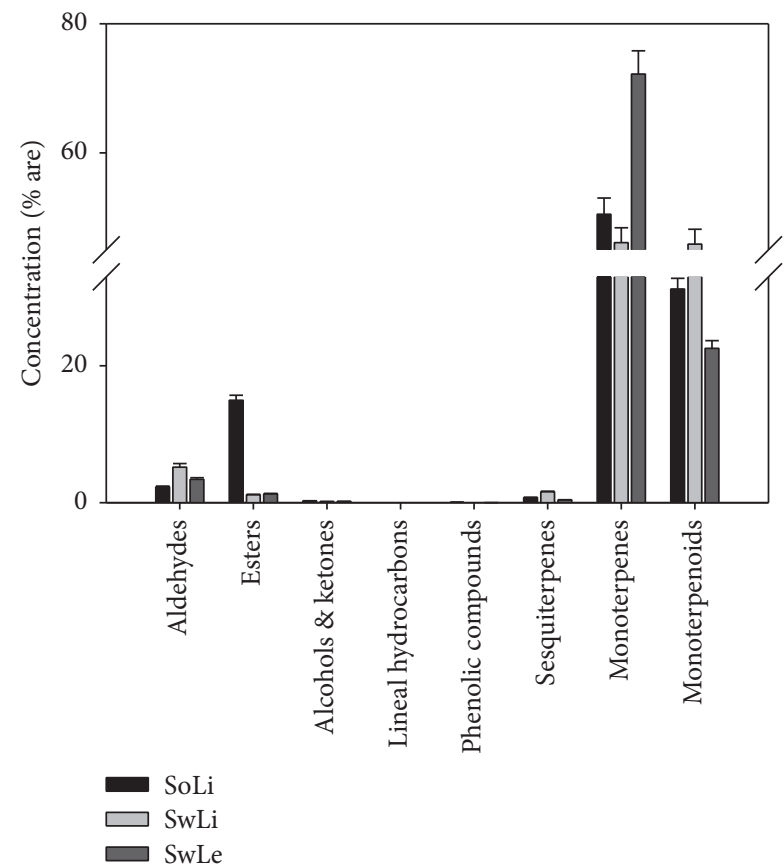

(a)

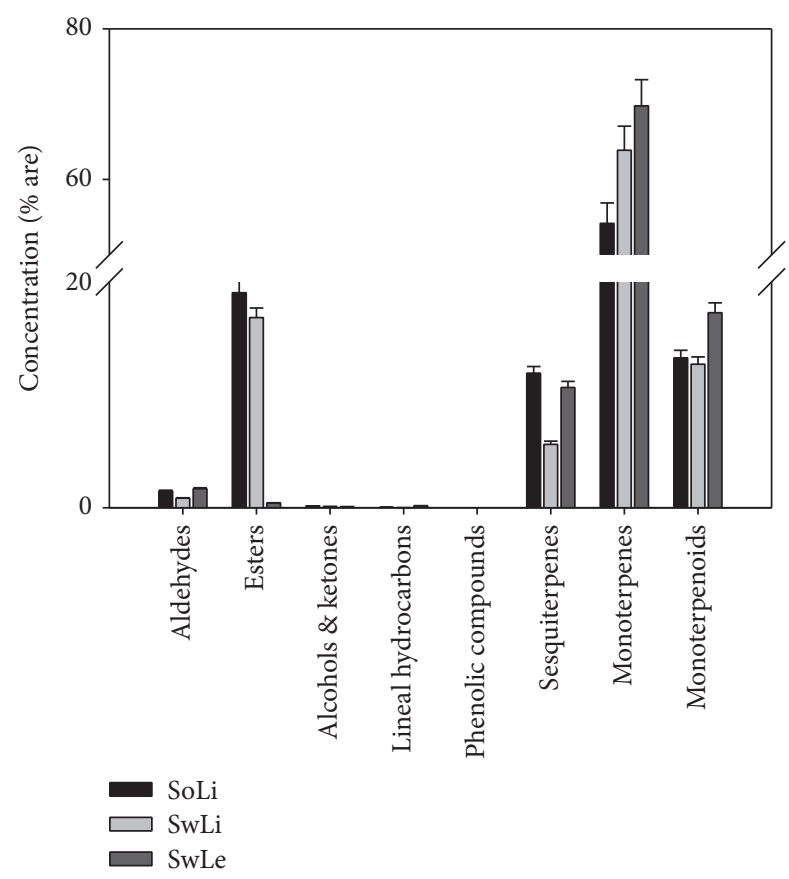

(b)

FIGURE 1: Total concentration (\% area) of each chemical family of volatile compounds in the juice (a) and peel (b) of endangered Spanish lime and lemon samples.

three families plus sesquiterpenes in the peels. The juice of the sour lime (SoLi) presented the highest content of esters $(14.8 \%)$ as compared to the other two products, with esters representing approximately $1 \%$ of the total area of the volatile compounds. The sweet lime (SwLi) juice presented similar values of both monoterpenes and monoterpenoids (46.1 and $46.0 \%$, resp.). Finally, the sweet lemon (SwLe) juice had the highest content of monoterpenes (72.2\%), with lower contents of monoterpenoids (22.9\%) and esters ( 1\%). Both types of limes (SoLi and SwLi) presented significantly higher esters contents in their peels as compared to SwLe $(<0.5 \%)$; also, their contents of monoterpenoids were similar (13.3 and $12.7 \%$, resp.). However, the SoLi had a higher content of sesquiterpenes than SwLi and vice versa. Finally, SwLe had the highest contents of monoterpenes (69.8\%) and monoterpenoids (17.3\%), but very low content of esters $(<0.5 \%)$.

In general, the five most abundant volatile compounds (in a decreasing order) in the juices of these three citrus fruits were limonene (mean of $47.1 \%)$, linalool (21.1\%), $\beta$-pinene $(4.7 \%)$, linalyl acetate $(4.6 \%)$, and geranial (4.0\%) (Table 4$)$. However, the relative order of these compounds changed among the citrus fruits studied; for instance, linalool was the predominant compound in sweet lime (SwLi). In this way, the exact order of the five most abundant compounds was SoLi: limonene $(44.7 \%)>$ linalool $(19.9 \%)>$ linalyl acetate $(13.2 \%)$ $>\alpha$-terpineol $(4.0 \%)>\beta$-pinene (3.7\%); SwLi: linalool $(40.6 \%)>$ limonene $(40.0 \%)>\beta$-pinene $(4.5 \%)>$ nonanal $(4.2 \%)>$ geranial $(2.1 \%)$; and, SwLe: limonene $(56.6 \%)>$ geranial $(8.3 \%)>\operatorname{neral}(6.7 \%)>\gamma$-terpinene $(6.0 \%)>\beta$ pinene (6.0\%).

Making a similar discussion with the peel data, it can be stated that the most abundant compounds (in a decreasing order) in the peels of these three citrus fruits were limonene (37.5\%), $\beta$-pinene (14.5\%), linalyl acetate (11.1\%), linalool (4.2\%), and $\alpha$-pinene (3.6\%) (Table 5). Again, differences were observed among the three studied citrus fruits, with the following five compounds predominating in: SoLi: limonene $(35.8 \%)>$ linalyl acetate $(17.1 \%)>\beta$-pinene $(11.3 \%)>$ linalool $(4.6 \%)>\beta$-bisabolene (4.2\%); SwLi: limonene $(40.9 \%)>\beta$ pinene $(16.6 \%)>$ linalyl acetate $(16.1 \%)>$ linalool $(7.7 \%)>$ $\alpha$-pinene (3.8\%); and, SwLe: limonene (35.9\%) > $\beta$-pinene $(15.7 \%)>\gamma$-terpinene $(8.7 \%)>$ geranial $(4.9 \%)>\alpha$-pinene (4.4\%).

If the ratio among the contents of the main volatile compounds in juice:peel is calculated, it can be easily observed that some compounds clearly predominate in the juice (ratio > 1) and include linalool (5.0) and geranial (1.7), while other compounds have similar concentrations in both juice and peel (ratio $\approx 1$ ), such as limonene (1.3), and others have much lower contents in the juice as compared to the peel $($ ratio $<1)$ and included linalyl acetate $(0.4), \beta$-pinene $(0.3)$, and $\alpha$-pinene (0.1).

3.4. Descriptive Sensory Analysis. The trained panel evaluated only the attributes show in Table 6 . The descriptive sensory analysis was useful in proving that the expected quality parameters of these highly endangered citrus fruits, native to 
TABLE 3: Retention indexes [8] and sensory descriptors [9-11] of the volatile compounds of endangered Spanish sour (SoLi) and sweet (SwLi) limes and sweet lemon (SwLe).

\begin{tabular}{|c|c|c|c|c|c|}
\hline \multirow{2}{*}{ Compounds } & \multirow{2}{*}{ Material $^{\dagger}$} & \multicolumn{3}{|c|}{ Retention indexes $^{\dagger}$} & \multirow{2}{*}{ Descriptors } \\
\hline & & $\operatorname{Exp}^{\dagger}$ & $\operatorname{Exp}^{\dagger}$ & $\mathrm{Lit}^{\dagger}$ & \\
\hline \multicolumn{6}{|l|}{ Aldehydes } \\
\hline Hexanal $^{\ddagger}$ & $\mathrm{J}, \mathrm{P}$ & 803 & 801 & 800 & Green \\
\hline 2-Hexenal & $\mathrm{J}, \mathrm{P}$ & 853 & 853 & 848 & Green, apple, sweet \\
\hline Heptanal & $\mathrm{J}$ & 904 & - & 903 & Hay, green \\
\hline 2-Heptenal & $\mathrm{J}$ & 961 & - & 951 & Lemon, green, apple \\
\hline Octanal & $\mathrm{J}, \mathrm{P}$ & 1006 & 1009 & 1006 & Citrus, fruity, honey \\
\hline 2-Octenal & $\mathrm{J}$ & 1061 & - & 1056 & Herbaceous, green \\
\hline Nonanal & $\mathrm{J}, \mathrm{P}$ & 1110 & 1128 & 1104 & Citrus, lime, lemon \\
\hline 2-Nonenal & $\mathrm{J}, \mathrm{P}$ & 1164 & 1185 & 1159 & Waxy, fatty \\
\hline 2-Decenal & $\mathrm{J}, \mathrm{P}$ & 1267 & 1277 & 1278 & Citrus, floral, waxy \\
\hline Perillaldehyde & $\mathrm{J}, \mathrm{P}$ & 1290 & 1300 & 1291 & Green, oily \\
\hline Undecanal & $\mathrm{P}$ & - & 1313 & 1310 & Orange, rose, fatty \\
\hline$(E, E)-2,4$-Decadienal & $\mathrm{P}$ & - & 1327 & 1316 & Butter, spicy \\
\hline Dodecanal & $\mathrm{J}, \mathrm{P}$ & 1412 & 1414 & 1420 & Floral, sweet, herbaceous \\
\hline \multicolumn{6}{|l|}{ Esters } \\
\hline Isoamyl acetate & $\mathrm{J}, \mathrm{P}$ & 880 & 871 & 876 & Banana, pear, sweet \\
\hline Hexyl acetate & $\mathrm{J}, \mathrm{P}$ & 1008 & 1009 & 1010 & Sweet, floral, apple \\
\hline Heptyl acetate & $\mathrm{J}$ & 1083 & - & 1085 & Citrus, pear, apricot \\
\hline Linalyl acetate & $\mathrm{J}, \mathrm{P}$ & 1250 & 1260 & 1257 & Floral, fruity, sweet \\
\hline Bornyl acetate & $\mathrm{J}, \mathrm{P}$ & 1294 & 1303 & 1289 & Woody, sweet \\
\hline Nonyl acetate & $\mathrm{P}$ & - & 1315 & 1311 & Fruity, gardenia \\
\hline Carvyl acetate & $\mathrm{J}$ & 1326 & - & 1333 & Sweet, green, minty \\
\hline p-Menth-1-en-9-yl acetate & $\mathrm{J}, \mathrm{P}$ & 1354 & 1356 & NA & \\
\hline Decyl acetate & $\mathrm{J}, \mathrm{P}$ & 1408 & 1410 & 1408 & Orange, pineapple, rose \\
\hline \multicolumn{6}{|l|}{ Lineal hydrocarbons } \\
\hline Tetradecane & $\mathrm{P}$ & - & 1400 & 1400 & Mild waxy \\
\hline \multicolumn{6}{|l|}{ Aliphatic alcohols, ketones } \\
\hline 1-Octanol & $\mathrm{J}, \mathrm{P}$ & 1077 & 1084 & 1072 & Citrus, woody, waxy \\
\hline Carvone & $\mathrm{J}$ & 1256 & - & 1248 & Minty, herbaceous \\
\hline Phenolic compounds & & & - & & \\
\hline 2-(2-Propenyl)-phenol & $\mathrm{J}$ & 1185 & - & 1157 & \\
\hline \multicolumn{6}{|l|}{ Sesquiterpenes } \\
\hline E- $\beta$-Caryophyllene & $\mathrm{J}, \mathrm{P}$ & 1437 & 1443 & 1428 & Woody, spicy \\
\hline$\beta$-Bergamotene & $\mathrm{J}, \mathrm{P}$ & 1422 & 1424 & 1436 & \\
\hline$\alpha$-Bergamotene & $\mathrm{J}, \mathrm{P}$ & 1442 & 1445 & 1446 & Woody \\
\hline$\alpha$-Humulene & $\mathrm{P}$ & - & 1474 & 1468 & Woody \\
\hline$\beta$-Santalene & $\mathrm{P}$ & - & 1472 & 1476 & Woody \\
\hline$(E, Z)-\alpha$-Farnesene & $\mathrm{P}$ & - & 1456 & 1477 & Lime, green, apple \\
\hline$\gamma$-Curcumene & $\mathrm{P}$ & - & 1486 & 1488 & \\
\hline$\alpha$-Farnesene & $\mathrm{P}$ & - & 1496 & 1505 & Lime, green, lavender \\
\hline$E$ - $\alpha$-Bisabolene & $\mathrm{J}, \mathrm{P}$ & 1507 & 1508 & 1506 & \\
\hline$\beta$-Bisabolene & $\mathrm{J}, \mathrm{P}$ & 1515 & 1521 & 1508 & Balsamic, woody \\
\hline$\gamma$-Bisabolene & $\mathrm{P}$ & - & 1548 & 1525 & \\
\hline \multicolumn{6}{|l|}{ Monoterpenes } \\
\hline$\alpha$-Thujene ${ }^{\ddagger}$ & $\mathrm{J}, \mathrm{P}$ & 930 & 932 & 923 & Woody, green, herb \\
\hline$\alpha$-Pinene & $\mathrm{J}, \mathrm{P}$ & 941 & 941 & 933 & Woody \\
\hline Camphene & $\mathrm{P}$ & & 961 & 953 & Vanilla \\
\hline Sabinene & $\mathrm{J}, \mathrm{P}$ & 980 & 985 & 973 & Woody, citrus, green \\
\hline$\beta$-Pinene & $\mathrm{J}, \mathrm{P}$ & 990 & 992 & 981 & Woody \\
\hline
\end{tabular}


TABLE 3: Continued.

\begin{tabular}{|c|c|c|c|c|c|}
\hline \multirow{2}{*}{ Compounds } & \multirow{2}{*}{ Material $^{\dagger}$} & \multicolumn{3}{|c|}{ Retention indexes $^{\dagger}$} & \multirow{2}{*}{ Descriptors } \\
\hline & & $\operatorname{Exp}^{\dagger}$ & $\operatorname{Exp}^{\dagger}$ & $\mathrm{Lit}^{\dagger}$ & \\
\hline$\alpha$-Terpinene & $\mathrm{J}, \mathrm{P}$ & 1024 & 1012 & 1014 & \\
\hline p-Cymene & $\mathrm{J}$ & 1034 & & 1027 & Citrus \\
\hline Limonene & $\mathrm{J}, \mathrm{P}$ & 1040 & 1066 & 1033 & Lemon, orange, sweet \\
\hline$\beta$-Phellandrene & $\mathrm{J}$ & 1042 & & 1034 & Herbaceous \\
\hline$E$ - $\beta$-Ocimene & $\mathrm{J}$ & 1046 & & 1042 & Sweet, herbal \\
\hline$\gamma$-Terpinene & $\mathrm{J}, \mathrm{P}$ & 1064 & 1076 & 1059 & Herbaceous, citrus \\
\hline$\alpha$-Terpinolene & $\mathrm{J}, \mathrm{P}$ & 1094 & 1100 & 1084 & Woody, sweet, pine \\
\hline Borneol & $\mathrm{J}$ & 1172 & & 1165 & Balsamic, pine, woody \\
\hline$\delta$-Terpineol & $\mathrm{J}, \mathrm{P}$ & 1183 & 1197 & 1167 & Pine, floral \\
\hline \multicolumn{6}{|l|}{ Monoterpenoids } \\
\hline 1,8-cineole & $\mathrm{J}$ & 1043 & - & 1035 & Citrus, fruity, sweet \\
\hline$Z$-Sabine hydrate & $\mathrm{P}$ & & 1086 & 1073 & Balsamic \\
\hline Linalool & $\mathrm{J}, \mathrm{P}$ & 1108 & 1113 & 1098 & Lemon, orange, sweet \\
\hline Limonene oxide & $\mathrm{J}$ & 1146 & & 1138 & Lemon, orange, sweet \\
\hline Citronellal & $\mathrm{J}, \mathrm{P}$ & 1155 & 1165 & 1154 & Lemon, green, sweet \\
\hline Terpinen-4-ol & $\mathrm{J}, \mathrm{P}$ & 1193 & 1209 & 1184 & \\
\hline$\alpha$-Terpineol & $\mathrm{J}$ & 1209 & & 1193 & Lilac \\
\hline Nerol & $\mathrm{P}$ & & 1236 & 1239 & Citrus \\
\hline Neral & $\mathrm{J}, \mathrm{P}$ & 1245 & 1248 & 1235 & Lemon \\
\hline Geranial & $\mathrm{J}, \mathrm{P}$ & 1273 & 1285 & 1277 & Lemon \\
\hline Citronellyl acetate & $\mathrm{J}$ & 1348 & & 1354 & Lemon, citrus, rose \\
\hline Neryl acetate & $\mathrm{J}, \mathrm{P}$ & 1359 & 1362 & 1365 & Lemon, lime, orange \\
\hline Geranyl acetate & $\mathrm{J}, \mathrm{P}$ & 1378 & 1382 & 1382 & Fruity, sweet, rose \\
\hline
\end{tabular}

${ }^{\dagger} \mathrm{J}=$ juice; $\mathrm{P}=$ peel; $\mathrm{RT}=$ retention time; Exp = experimental; and Lit = literature. ${ }^{\ddagger}$ All compounds were identified using retention indexes, mass spectra, and retention time of standards. ${ }^{9}$ References [9-11].

the Mediterranean coast of Spain, were met (Figure 2). The color of the fruits was completely different among them, while the SoLi is dark green (1.0), the SwLi is greenish (4.7), and the SwLe is intense yellow (9.2). None of these products were either bitter or astringent, although the SoLi was the bitterest (2.8) and most astringent (1.2) fruit. The sour and bitter tastes predominated in SoLi as expected, and as indicated in their names. The sweetness of the SwLe (8.5) is higher than that of the SwLi (6.5), and the sourness of the SoLi reaches a value of 8.0 , in a scale up to 10 . The product with the highest floral notes in both the juice and peel is SoLi (6.0 and 5.0, resp.), while the peel of the SwLi has an intense citric note (6.3), and the peel of the SwLe has intense green and citric notes $(>8.5)$.

The most complex flavor of the three studied products is that of the SoLi, of which juice has simultaneously high intensities of citric (8.2), floral (6.0), and green (5.0) notes. This potent combination is what makes SoLi the most popular citrus fruit in countries such as Mexico, where consumers are very much used to intense flavors. Mexican people use SoLi in almost every single dish, including for instance beer. This practice is not frequent in Mediterranean countries, but perhaps in a future and due to the internationalization of the foods a higher demand of SoLi in the Mediterranean countries can be expected; this expectation of the high number of people from South America that is living in Spain is even more reliable especially during the times when the economy is in good shape.

Pearson's correlation coefficient (Table 7) showed that floral, green, and citrus notes were positively correlated $(R=0.99 ; p$ value $=0.025,0.032$ and 0.081 , resp.; $p<$ $0.001)$ with esters content regarding juices. No significant $(p>0.05)$ correlation was observed among sensory data with sesquiterpenes, monoterpenes, and monoterpenoids. As to peel, Pearson's coefficient showed that floral notes was positively correlated $(R=0.95 ; p$ value $=0.21 ; p<$ $0.01)$ with esters and inversely correlated $(R=-0.98$ and $-0.85 ; p$ value $=0.14$ and $0.35 ; p<0.001$ and 0.05 , resp.) with monoterpenes and monoterpenoids. Aversely, green and citrus notes were inversely correlated $(R=-0.99 ; p$ value $=$ 0.004 and 0.007 , resp.; $p<0.001)$ with esters and positively with monoterpenes $(R \approx 0.85 ; p$ value $=0.35 ; p<0.05)$ and monoterpenoids $(R=0.97 ; p$ value $=0.13 ; p<0.001$, resp. $)$.

The first two PC dimensions (PC1 and PC2) explained $69 \%$ of the variability of the experimental data from this study (Figure 3). The profile of the juice of the SwLe (SwLe J) was characterized by high contents of limonene, geranial, and neral, while that of SwLi was controlled by the high levels of linalool and nonanal; finally, the juice of the SoLi had high contents of linalyl acetate, $\alpha$-terpineol, octanal, and terpinen-4-ol. Regarding the peel of the SoLi, its profile was 
TABLE 4: Volatile compounds (\%) in the juice of endangered Spanish sour (SoLi) and sweet (SwLi) limes and sweet lemon (SwLe).

\begin{tabular}{|c|c|c|c|c|c|c|}
\hline \multirow{2}{*}{ Compound } & \multirow{2}{*}{ RT (min) } & \multirow{2}{*}{ Code } & \multirow{2}{*}{$\mathrm{ANOVA}^{\dagger}$} & \multicolumn{3}{|c|}{ Content (\%) } \\
\hline & & & & SoLi & SwLi & SwLe \\
\hline Hexanal & 7.36 & $\mathrm{~J} 1$ & $*$ & $0.22 \mathrm{a}$ & $0.05 \mathrm{~b}$ & $0.28 \mathrm{a}$ \\
\hline E-2-Hexenal & 8.35 & JP1 & $*$ & $0.07 \mathrm{~b}$ & $0.06 \mathrm{~b}$ & $0.28 \mathrm{a}$ \\
\hline Isoamyl acetate & 8.88 & $\mathrm{~J} 2$ & NS & 0.05 & $\mathrm{Nd}$ & $\mathrm{Nd}$ \\
\hline Heptanal & 9.38 & $\mathrm{~J} 3$ & NS & 0.02 & $\mathrm{Nd}$ & 0.03 \\
\hline$\alpha$-Thujene & 10.18 & JP2 & NS & $\mathrm{Nd}$ & 0.02 & 0.17 \\
\hline$\alpha$-Pinene & 10.49 & JP3 & $* *$ & $0.27 \mathrm{~b}$ & $0.20 \mathrm{~b}$ & $0.59 \mathrm{a}$ \\
\hline 2-Heptenal & 11.08 & $\mathrm{~J} 4$ & NS & 0.10 & 0.03 & 0.12 \\
\hline Sabinene & 11.66 & JP4 & $* *$ & $0.11 \mathrm{~b}$ & $0.58 \mathrm{ab}$ & $0.78 \mathrm{a}$ \\
\hline$\beta$-Pinene & 11.97 & JP5 & $* *$ & $3.66 \mathrm{~b}$ & $4.35 \mathrm{~b}$ & $5.98 \mathrm{a}$ \\
\hline Octanal & 12.47 & JP6 & $* *$ & $1.40 \mathrm{a}$ & $0.65 \mathrm{~b}$ & $0.79 \mathrm{~b}$ \\
\hline Hexyl acetate & 12.56 & JP7 & $* * *$ & $0.52 \mathrm{a}$ & $0.02 \mathrm{~b}$ & $0.04 \mathrm{~b}$ \\
\hline$\alpha$-Terminene & 13.19 & JP8 & NS & 0.10 & 0.05 & 0.18 \\
\hline$p$-Cymene & 13.57 & $\mathrm{~J} 5$ & $* *$ & $0.04 \mathrm{~b}$ & $0.03 \mathrm{~b}$ & $0.67 \mathrm{a}$ \\
\hline Limonene & 13.81 & JP9 & $* * *$ & $44.7 \mathrm{~b}$ & $40.0 \mathrm{c}$ & $56.6 \mathrm{a}$ \\
\hline$\beta$-Phellandrene & 13.88 & $\mathrm{~J} 6$ & NS & 0.34 & 0.39 & 0.50 \\
\hline 1,8-Cineole & 13.92 & J7 & $* *$ & $0.19 \mathrm{~b}$ & $0.16 \mathrm{~b}$ & $0.33 \mathrm{a}$ \\
\hline$E$ - $\beta$-Ocimene & 14.03 & J8 & $*$ & $0.35 \mathrm{a}$ & $0.19 \mathrm{~b}$ & $0.23 \mathrm{ab}$ \\
\hline 2-Octenal & 14.62 & J9 & $* * *$ & $0.07 \mathrm{~b}$ & $0.02 \mathrm{~b}$ & $0.39 \mathrm{a}$ \\
\hline$\gamma$-Terpinene & 14.72 & JP10 & $* * *$ & $0.41 \mathrm{~b}$ & $0.17 \mathrm{c}$ & $6.03 \mathrm{a}$ \\
\hline 1-Octanol & 15.23 & JP11 & NS & 0.04 & 0.02 & 0.02 \\
\hline Heptyl acetate & 15.47 & $\mathrm{~J} 10$ & NS & 0.04 & 0.04 & 0.01 \\
\hline$\alpha$-Terpinolene & 15.87 & JP12 & $* * *$ & $0.44 \mathrm{a}$ & $0.05 \mathrm{~b}$ & $0.31 \mathrm{a}$ \\
\hline Linalool & 16.49 & JP13 & $* * *$ & $19.9 \mathrm{~b}$ & $40.6 \mathrm{a}$ & $2.74 \mathrm{c}$ \\
\hline Nonanal & 16.55 & JP14 & $* * *$ & $0.20 \mathrm{c}$ & $4.09 \mathrm{a}$ & $1.06 \mathrm{~b}$ \\
\hline Limonene oxide & 18.18 & $\mathrm{~J} 11$ & $* *$ & $0.05 \mathrm{~b}$ & $0.04 \mathrm{~b}$ & $0.24 \mathrm{a}$ \\
\hline Citronellal & 18.55 & JP15 & $* *$ & $0.02 \mathrm{~b}$ & $0.10 \mathrm{~b}$ & $0.52 \mathrm{a}$ \\
\hline 2-Nonenal & 18.96 & JP16 & NS & $0.04 \mathrm{~b}$ & $0.04 \mathrm{~b}$ & $0.25 \mathrm{a}$ \\
\hline Borneol & 19.32 & $\mathrm{~J} 12$ & NS & 0.04 & 0.02 & 0.01 \\
\hline$\delta$-Terpineol & 19.78 & JP17 & NS & 0.03 & 0.04 & 0.15 \\
\hline 2-(2-Propenyl)-phenol & 19.87 & $\mathrm{~J} 13$ & NS & 0.07 & $\mathrm{Nd}$ & 0.01 \\
\hline Terpinen-4-ol & 20.25 & JP18 & $* * *$ & $1.08 \mathrm{a}$ & $0.36 \mathrm{~b}$ & $0.86 \mathrm{ab}$ \\
\hline$\alpha$-Terpineol & 20.96 & JP19 & $* * *$ & $3.95 \mathrm{a}$ & $1.07 \mathrm{c}$ & $2.99 \mathrm{~b}$ \\
\hline Neral & 22.63 & JP20 & $* * *$ & $0.91 \mathrm{c}$ & $1.57 \mathrm{~b}$ & $6.73 \mathrm{a}$ \\
\hline Linalyl acetate & 22.85 & JP21 & $* * *$ & $13.2 \mathrm{a}$ & $0.36 \mathrm{~b}$ & $0.12 \mathrm{~b}$ \\
\hline Carvone & 23.14 & JP22 & NS & 0.19 & 0.10 & 0.13 \\
\hline 2-Decenal & 23.66 & JP23 & NS & 0.08 & 0.04 & 0.05 \\
\hline Geranial & 23.96 & JP24 & $* * *$ & $1.55 \mathrm{~b}$ & $2.10 \mathrm{~b}$ & $8.28 \mathrm{a}$ \\
\hline Perillaldehyde & 24.73 & JP25 & NS & 0.08 & 0.18 & 0.14 \\
\hline Bornyl acetate & 24.91 & JP26 & NS & 0.11 & 0.17 & 0.01 \\
\hline Caryl acetate & 26.41 & $\mathrm{~J} 14$ & NS & 0.28 & 0.35 & 0.76 \\
\hline Citronellyl acetate & 27.40 & JP27 & NS & 0.17 & 0.01 & 0.02 \\
\hline$p$-Menth-1-en-9-yl acetate acetate & 27.67 & JP28 & NS & 0.51 & 0.04 & nd \\
\hline Neryl acetate & 27.89 & JP29 & $* * *$ & $1.63 \mathrm{a}$ & $0.01 \mathrm{~b}$ & $0.12 \mathrm{~b}$ \\
\hline Geranyl acetate & 28.80 & JP30 & $* * *$ & $1.96 \mathrm{a}$ & $0.01 \mathrm{~b}$ & $0.04 \mathrm{~b}$ \\
\hline Decyl acetate & 30.16 & JP31 & NS & 0.05 & 0.01 & 0.01 \\
\hline Dodecanal & 30.35 & JP32 & NS & 0.02 & 0.02 & 0.02 \\
\hline$\beta$-Bergamotene & 30.78 & JP33 & NS & 0.01 & 0.02 & 0.01 \\
\hline$\beta$-Caryophyllene & 31.43 & JP34 & NS & 0.07 & 0.14 & 0.07 \\
\hline
\end{tabular}


TABLE 4: Continued.

\begin{tabular}{|c|c|c|c|c|c|c|}
\hline \multirow{2}{*}{ Compound } & \multirow{2}{*}{$\mathrm{RT}(\min )$} & \multirow{2}{*}{ Code } & \multirow{2}{*}{$\mathrm{ANOVA}^{\dagger}$} & \multicolumn{3}{|c|}{ Content (\%) } \\
\hline & & & & SoLi & SwLi & SwLe \\
\hline$\alpha$-Bergamotene & 31.67 & JP35 & NS & 0.30 & 0.45 & 0.14 \\
\hline$\alpha$-Bisabolene & 34.54 & JP36 & NS & 0.04 & 0.05 & 0.04 \\
\hline$\beta$-Bisabolene & 34.92 & JP36 & $* * *$ & $0.32 \mathrm{ab}$ & $0.93 \mathrm{a}$ & $0.15 \mathrm{~b}$ \\
\hline
\end{tabular}

${ }^{\dagger} \mathrm{NS}=$ not significant at $p<0.05 ;{ }^{*, * * * * *}$ significant at $p<0.05,0.01$, and 0.001 , respectively; values (mean of 3 replications) followed by the same letter, within the same row, were not significantly different $(p<0.05)$, according to Tukey's least significant difference test.

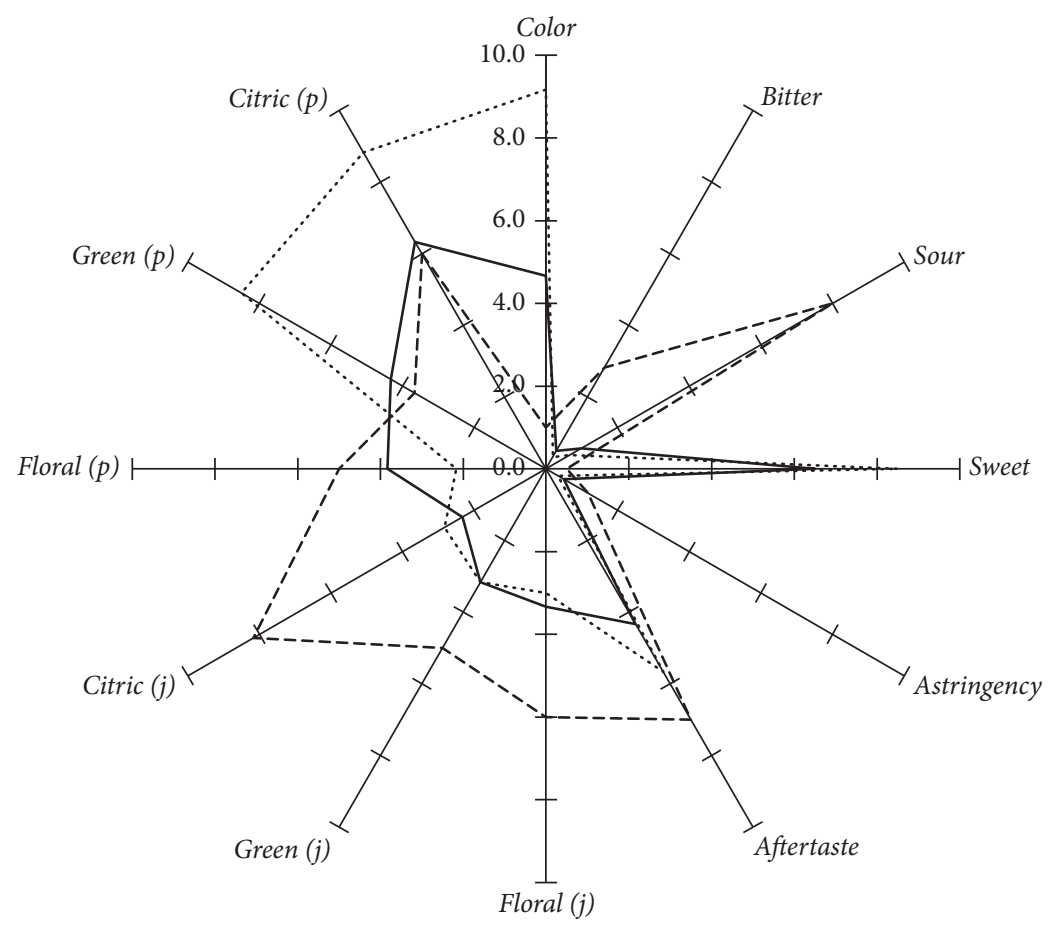

$$
\begin{aligned}
& \text {--- Acid lime } \\
& \text { - Sweet lime } \\
& \text {..... Sweet lemon }
\end{aligned}
$$

FIGURE 2: Descriptive sensory analysis (DSA) of flavor attributes in endangered Spanish lime and lemon samples (j: juice, p: peel).

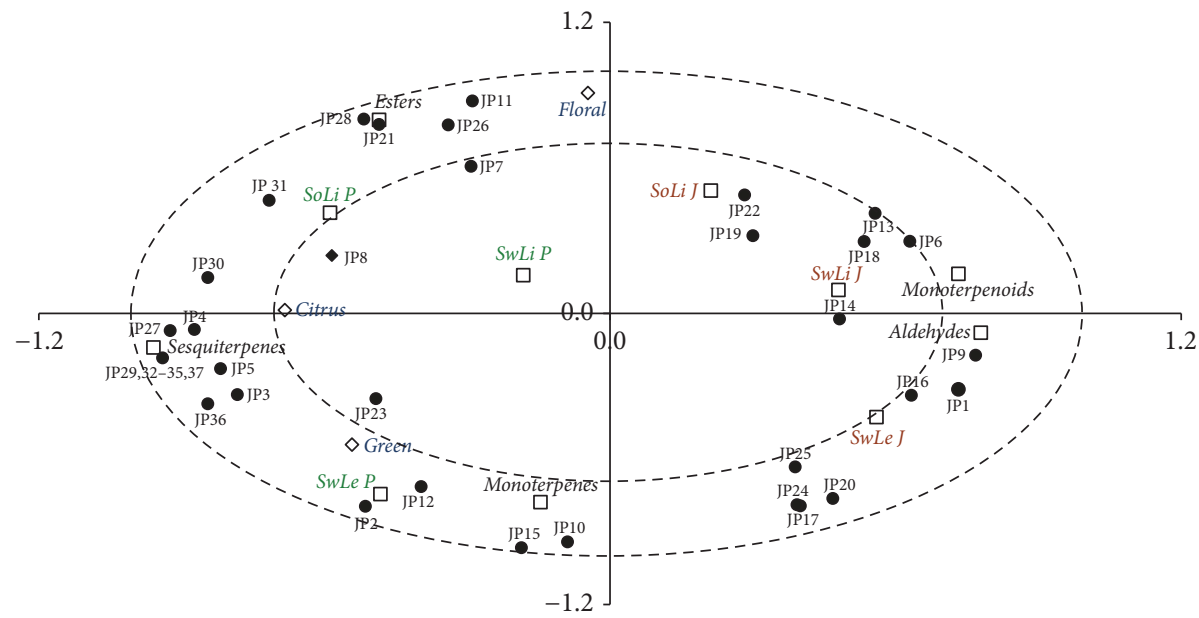

(X-exp: $41 \%, 28 \%)$

FIGURE 3: PCA map showing the relationships among volatile compounds, chemical families, and sensory attributes of endangered Spanish lime and lemon samples. 
TABLE 5: Volatile compounds (\%) in the peel of endangered Spanish sour (SoLi) and sweet (SwLi) limes and sweet lemon (SwLe).

\begin{tabular}{|c|c|c|c|c|c|c|}
\hline \multirow{2}{*}{ Compound } & \multirow{2}{*}{ RT } & \multirow{2}{*}{ Code } & \multirow{2}{*}{$\mathrm{ANOVA}^{\dagger}$} & \multicolumn{3}{|c|}{ Content (\%) } \\
\hline & & & & SoLi & SwLi & SwLe \\
\hline E-2-Hexenal & 8.36 & JP1 & NS & 0.01 & 0.01 & 0.01 \\
\hline$\alpha$-Thujene & 10.22 & JP2 & $* * *$ & $0.14 \mathrm{~b}$ & $0.11 \mathrm{~b}$ & $1.12 \mathrm{a}$ \\
\hline$\alpha$-Pinene & 10.50 & JP3 & $* * *$ & $2.64 \mathrm{~b}$ & $3.76 \mathrm{ab}$ & $4.42 \mathrm{a}$ \\
\hline Camphene & 11.08 & P1 & $* *$ & $0.15 \mathrm{~b}$ & $0.48 \mathrm{a}$ & $0.16 \mathrm{~b}$ \\
\hline Sabinene & 11.79 & JP4 & $* * *$ & $2.90 \mathrm{a}$ & $1.81 \mathrm{~b}$ & $1.92 \mathrm{~b}$ \\
\hline$\beta$-Pinene & 12.03 & JP5 & $* *$ & $11.3 \mathrm{~b}$ & $16.6 \mathrm{a}$ & $15.7 \mathrm{ab}$ \\
\hline Octanal & 12.51 & JP6 & $* *$ & $0.27 \mathrm{a}$ & $0.02 \mathrm{~b}$ & $0.33 \mathrm{a}$ \\
\hline Hexyl acetate & 12.62 & JP7 & $* *$ & $0.41 \mathrm{a}$ & $0.01 \mathrm{~b}$ & $0.12 \mathrm{ab}$ \\
\hline$\alpha$-Terpinene & 12.71 & JP8 & $* *$ & $0.80 \mathrm{a}$ & $0.01 \mathrm{~b}$ & $0.19 \mathrm{ab}$ \\
\hline Limonene & 14.82 & JP9 & $* * *$ & $35.8 \mathrm{~b}$ & $40.9 \mathrm{a}$ & $35.9 \mathrm{~b}$ \\
\hline$\gamma$-Terpinene & 15.18 & JP10 & $* * *$ & $0.29 \mathrm{~b}$ & $0.09 \mathrm{c}$ & $8.69 \mathrm{a}$ \\
\hline 1-Octanol & 15.51 & JP11 & NS & 0.05 & 0.03 & 0.01 \\
\hline$Z$-Sabine hydrate & 15.58 & $\mathrm{P} 2$ & NS & 0.06 & 0.07 & 0.09 \\
\hline$\alpha$-Terpinolene & 16.10 & JP12 & $* * *$ & $0.13 \mathrm{~b}$ & $0.10 \mathrm{~b}$ & $1.57 \mathrm{a}$ \\
\hline Linalool & 16.62 & JP13 & $* * *$ & $4.56 \mathrm{~b}$ & $7.67 \mathrm{a}$ & $0.60 \mathrm{c}$ \\
\hline Nonanal & 17.20 & JP14 & NS & 0.79 & 0.57 & 0.72 \\
\hline Citronellal & 18.63 & JP15 & $* * *$ & $0.13 \mathrm{~b}$ & $0.15 \mathrm{~b}$ & $0.78 \mathrm{a}$ \\
\hline 2-Nonenal & 19.39 & JP16 & NS & 0.03 & 0.01 & 0.01 \\
\hline$\delta$-Terpineol & 19.85 & JP17 & NS & 0.02 & 0.02 & 0.09 \\
\hline Terpinen-4-ol & 20.33 & JP18 & NS & 0.46 & 0.11 & 0.19 \\
\hline$\alpha$-Terpineol + Octyl acetate & 21.08 & JP19 & $* * *$ & $2.18 \mathrm{a}$ & $1.31 \mathrm{~b}$ & $1.40 \mathrm{~b}$ \\
\hline Nerol & 22.13 & P3 & NS & 0.03 & 0.01 & 0.01 \\
\hline Neral & 22.69 & JP20 & $* * *$ & $0.14 \mathrm{~b}$ & $0.09 \mathrm{~b}$ & $3.48 \mathrm{a}$ \\
\hline Linalyl acetate & 23.22 & JP21 & $* * *$ & $17.1 \mathrm{a}$ & $16.1 \mathrm{a}$ & $0.18 \mathrm{~b}$ \\
\hline Carvone & 23.83 & JP22 & NS & 0.07 & 0.05 & 0.06 \\
\hline 2-Decenal & 23.98 & JP23 & NS & 0.07 & 0.03 & 0.11 \\
\hline Geranial & 24.30 & JP24 & $* * *$ & $1.14 \mathrm{~b}$ & $1.14 \mathrm{~b}$ & $4.86 \mathrm{a}$ \\
\hline Perillaldehyde & 24.97 & JP25 & NS & 0.09 & 0.11 & 0.15 \\
\hline Bornyl acetate & 25.11 & JP26 & NS & 0.22 & 0.16 & 0.04 \\
\hline Nonyl acetate & 25.67 & $\mathrm{P} 4$ & NS & 0.09 & 0.04 & 0.03 \\
\hline Undecanal & 25.78 & P5 & NS & 0.04 & 0.02 & 0.23 \\
\hline$(E, E)-2,4$-Decadienal & 26.43 & P6 & NS & 0.06 & 0.02 & 0.01 \\
\hline Citronellyl acetate & 27.55 & JP27 & NS & 0.38 & 0.12 & 0.38 \\
\hline p-Menth-1-en-9-yl acetate & 27.78 & JP28 & NS & 0.82 & 0.40 & $\mathrm{Nd}$ \\
\hline Neryl acetate & 28.07 & JP29 & $* * *$ & $1.88 \mathrm{ab}$ & $0.96 \mathrm{~b}$ & $3.18 \mathrm{a}$ \\
\hline Geranyl acetate & 28.99 & JP30 & $* * *$ & $2.31 \mathrm{a}$ & $1.08 \mathrm{~b}$ & $2.30 \mathrm{a}$ \\
\hline Tetradecane & 29.82 & JP31 & NS & 0.03 & 0.02 & 0.15 \\
\hline Decyl acetate & 30.24 & JP32 & NS & 0.40 & 0.13 & 0.05 \\
\hline Dodecanal & 30.44 & P7 & NS & 0.12 & 0.05 & 0.11 \\
\hline$\beta$-Bergamotene & 30.88 & JP33 & NS & 0.42 & 0.18 & 0.30 \\
\hline$E$ - $\beta$-Caryophyllene & 31.58 & JP34 & $* *$ & $1.51 \mathrm{a}$ & $0.84 \mathrm{~b}$ & $1.33 \mathrm{ab}$ \\
\hline$\alpha$-Bergamotene & 31.88 & JP35 & $* * *$ & $3.81 \mathrm{a}$ & $1.79 \mathrm{~b}$ & $2.88 \mathrm{ab}$ \\
\hline$(E, Z)$ - $\alpha$-Farnesene & 32.31 & P8 & NS & 0.44 & 0.17 & 0.43 \\
\hline$\beta$-Santalene & 32.99 & P9 & NS & 0.22 & 0.10 & 0.24 \\
\hline$\alpha$-Humulene & 33.12 & $\mathrm{P} 10$ & NS & 0.15 & 0.08 & 0.14 \\
\hline$\gamma$-Curcumene & 33.65 & P11 & NS & 0.10 & 0.03 & 0.12 \\
\hline$\alpha$-Farnesene & 34.09 & $\mathrm{P} 12$ & NS & 0.35 & 0.14 & 0.25 \\
\hline
\end{tabular}


TABLE 5: Continued.

\begin{tabular}{|c|c|c|c|c|c|c|}
\hline \multirow{2}{*}{ Compound } & \multirow{2}{*}{ RT } & \multirow{2}{*}{ Code } & \multirow{2}{*}{$\mathrm{ANOVA}^{\dagger}$} & \multicolumn{3}{|c|}{ Content (\%) } \\
\hline & & & & SoLi & SwLi & SwLe \\
\hline$E$ - $\alpha$-Bisabolene & 34.61 & JP36 & NS & 0.55 & 0.23 & 0.91 \\
\hline$\beta$-Bisabolene & 35.15 & JP37 & $* * *$ & $4.23 \mathrm{a}$ & $2.00 \mathrm{~b}$ & $3.90 \mathrm{a}$ \\
\hline$\gamma$-Bisabolene & 36.30 & $\mathrm{P} 13$ & NS & 0.13 & 0.05 & 0.15 \\
\hline
\end{tabular}

${ }^{\dagger} \mathrm{NS}=$ not significant at $p<0.05 ;{ }^{* *, * * *}$ significant at $p<0.05,0.01$, and 0.001 , respectively; values (mean of 3 replications) followed by the same letter, within the same row, were not significantly different $(p<0.05)$, according to Tukey's least significant difference test.

TABLE 6: Flavor attributes selected for descriptive sensory analysis.

\begin{tabular}{|c|c|c|}
\hline Attribute & Definition & References $^{*}$ \\
\hline Color & Visual evaluation of the color intensity of the sample & $\begin{array}{l}\text { Pantone } 102 \mathrm{U}=1.0 \text {; Pantone } \\
\text { Process Yellow } \mathrm{C}=5.0 \text {; Pantone } \\
13-0630 \mathrm{TN}=9.0\end{array}$ \\
\hline Bitter & Taste associated with caffeine & $\begin{array}{l}0,008 \% \text { caffeine solution }=1,0 \\
0,015 \% \text { caffeine solution }=2,0\end{array}$ \\
\hline Sour & $\begin{array}{l}\text { The fundamental taste factor associated with some } \\
\text { organic acid, especially citric acid }\end{array}$ & $\begin{array}{l}0,043 \% \text { citric acid solution }=2,0 \\
0,064 \% \text { citric acid solution }=3,0 \\
0,120 \% \text { citric acid solution }=5,0 \\
0,168 \% \text { citric acid solution }=7,0\end{array}$ \\
\hline Sweet & $\begin{array}{l}\text { The fundamental taste factor associated with a sucrose } \\
\text { solution }\end{array}$ & $\begin{array}{l}3 \% \text { sucrose solution }=2,0 \\
6 \% \text { sucrose solution }=4,0\end{array}$ \\
\hline Astringency & Causing contraction of mouth tissues & $\begin{array}{l}0.03 \% \text { alum solution }=1.5 \\
0.05 \% \text { alum solution }=2.5 \\
0.1 \% \text { alum solution }=5.0\end{array}$ \\
\hline Aftertaste & Remaining desirable flavor after swallowing & $\begin{array}{l}0 \text { seconds }=0 \\
\text { Seconds }=5 \\
<60 \text { seconds }=10\end{array}$ \\
\hline Floral & $\begin{array}{l}\text { Flavor associated with flower, remembering some } \\
\text { fragrances }\end{array}$ & Geraniol $\left(1000\right.$ microgL $\left.^{-1}\right)=4.0$ \\
\hline Green & Fresh aromatics associated with green vegetables & $\begin{array}{l}\text { trans-2-Hexen-1-ol 5,000 } \mathrm{ppm}= \\
4.0 \\
\text { Fresh sliced tomatoes }=10.0\end{array}$ \\
\hline Citric & Volatile compounds associated with lemon or lime & $\begin{array}{l}\text { Fresh-squeezed orange juice }=8 \\
\text { Fresh-squeezed orange juice } \\
\text { diluted } 1: 1=4\end{array}$ \\
\hline
\end{tabular}

${ }^{¥}$ Reference [12].

TABLE 7: Pearson's correlation coefficients among sensory descriptive attributes (floral, green, and citrus) and total content of the main volatile families (esters, sesquiterpenes, monoterpenes, and monoterpenoids) of the juice and peel of endangered Spanish lime and lemon samples.

\begin{tabular}{lcccc}
\hline Attribute & Esters & Sesquiterpenes & $\begin{array}{c}\text { Monoterpenes } \\
\text { JUICE, Pearson's correlation coefficients }\end{array}$ \\
\hline Floral & & -0.16 & -0.44 & Monoterpenoids \\
Green & $0.99^{* * * \dagger}$ & -0.25 & -0.36 & -0.06 \\
Citrus & $0.99^{* * * \dagger}$ & -0.32 & -0.29 & -0.15 \\
\hline & $0.99^{* * * \dagger}$ & PEEL, Pearson's correlation coefficients & -0.22 \\
\hline Floral & $0.95^{* * \dagger}$ & 0.11 & $-0.98^{* * * \dagger}$ & $-0.85^{* \dagger}$ \\
Green & $-0.99^{* * * \dagger}$ & 0.22 & $0.85^{* \dagger}$ & $0.97^{* * * \dagger}$ \\
Citrus & $-0.99^{* * \dagger}$ & 0.23 & $0.84^{* \dagger}$ & $0.98^{* * * \dagger}$ \\
\hline
\end{tabular}

${ }^{\dagger} *, * *$, and $* * *$ denote significant correlations at $p<0.05,0.01$, and 0.001 , respectively. 
controlled by high levels of linalyl acetate, hexyl acetate, and $\alpha$-terpinene, while that of SwLi was related to the contents of hexyl acetate and $\alpha$-terpinene; finally, SwLe peel had contents of $\alpha$-terpinene, $\alpha$-pinene, citronellal, and $\alpha$-terpiolene, plus high green notes.

\section{Conclusions}

The descriptive sensory analysis helped in demonstrating the high potential of these three Citrus specimens. For instance, the sour lime has a very intense sour taste and high intensities of all key citrus flavor notes and with a long aftertaste; this sensory profile makes this fruit absolutely attractive for consumers willing to have a strong citrus flavor in their dishes, such as Mexican people living in Europe. On the other hand, the sweet lime and sweet lemons have a surprising sweet taste, which is completely unexpected for European consumers which are used to the sour taste of the citrus products. Besides, these two sweet citrus fruits have relatively high floral and green notes, which are associated with long aftertaste. The above described sensory attributes are supported by instrumental analysis proving that citric acid predominated in the sour lime, but glucose and fructose predominated in the sweet lime, and equilibrium among citric acid, glucose, and fructose was found in the sweet lemon. Finally, the volatile composition consisted mainly of monoterpenes, monoterpenoids, and esters (juices), plus sesquiterpenes (peels); these volatile profiles are typical of citrus fruits. Thus, the combination of citrus flavor, with strong sour taste (sour lime) and with an unexpected sweet taste (sweet lemon and lime), will make these materials highly demanded by consumers. The high demand by Spanish and European consumers hopefully will convince farmers of the potential of these three endangered citrus fruits and will make them cultivate them intensively again.

\section{Conflicts of Interest}

Authors declare that there are no conflicts of interest regarding the publication of this paper.

\section{Acknowledgments}

Author Marina Cano-Lamadrid was funded by a FPU grant from the Spanish Ministry of Education (FPU15/02158).

\section{References}

[1] "Citriculture The Citrus Industry, Vol. II, Anatomy, Physiology, Genetics, and Reproduction W. Reuther H. J. Webber L. D. Batchelor," Bioscience, vol. 19, no. 6, pp. 572-572, 1969.

[2] S. Dayal, J. Murray, K. Wilson, and A. Lannigan, "Vastagtübiopsziás hengerből készített imprint citológia növeli a vékonytü-aspirációs citológia szenzitivitását emlörákos betegekben," Magyar Sebészet, vol. 64, no. 2, pp. 59-62, 2011.

[3] FAO, Food and Agriculture Organization of the United Nations Statistics Division, 2016.

[4] H. Kelebek and S. Selli, "Determination of volatile, phenolic, organic acid and sugar components in a Turkish cv. Dortyol
(Citrus sinensis L. Osbeck) orange juice," Journal of the Science of Food and Agriculture, vol. 91, no. 10, pp. 1855-1862, 2011.

[5] M. C. González-Mas, J. L. Rambla, M. C. Alamar, A. Gutiérrez, and A. Granell, "Comparative analysis of the volatile fraction of fruit juice from different citrus species," PLoS ONE, vol. 6, no. 7, Article ID e22016, 2011.

[6] A. Buettner and P. Schieberle, "Evaluation of aroma differences between hand-squeezed juices from Valencia late and Navel oranges by quantitation of key odorants and flavor reconstitution experiments," Journal of Agricultural and Food Chemistry, vol. 49, no. 5, pp. 2387-2394, 2001.

[7] H. M. S. Ziena, "Quality attributes of Bearss Seedless lime (Citrus latifolia Tan) juice during storage," Food Chemistry, vol. 71, no. 2, pp. 167-172, 2000.

[8] F. Hernández, L. Noguera-Artiaga, F. Burló, A. Wojdyło, Á. A. Carbonell-Barrachina, and P. Legua, "Physico-chemical, nutritional, and volatile composition and sensory profile of Spanish jujube (Ziziphus jujuba Mill.) fruits," Journal of the Science of Food and Agriculture, vol. 96, no. 8, pp. 2682-2691, 2016.

[9] A. Galindo, L. Noguera-Artiaga, Z. N. Cruz et al., "Sensory and physico-chemical quality attributes of jujube fruits as affected by crop load," LWT- Food Science and Technology, vol. 63, no. 2, pp. 899-905, 2015.

[10] S. V. Ting and R. L. Rouseff, "Chemical constituents affecting quality characteristics of citrus products," in Citrus Fruits and Their Products. Analysis and Technology, pp. 73-120, Marcel Dekker, New York, NY, USA, 1986.

[11] "NIST database," http://webbook.nist.gov/chemistry/nameser.html.

[12] M. Meilgaard and G. V. Civille, Sensory Evaluation Techniques: Third Edition, CRC Press LLC, New York, 1999.

[13] A. A. Carbonell-Barrachina, A. Calín-Sánchez, B. Bagatar et al., "Potential of Spanish sour-sweet pomegranates (cultivar C25) for the juice industry," Food Science and Technology International, vol. 18, no. 2, pp. 129-138, 2012.

[14] P. Melgarejo, Á. Calín-Sánchez, Á. A. Carbonell-Barrachina et al., "Antioxidant activity, volatile composition and sensory profile of four new very-early apricots (Prunus armeniaca L.)," Journal of the Science of Food and Agriculture, vol. 94, no. 1, pp. 85-94, 2014.

[15] L. Vázquez-Araújo, E. Chambers, K. Adhikari, and A. A. Carbonell-Barrachina, "Physico-chemical and sensory properties of pomegranate juices with pomegranate albedo and carpellar membranes homogenate," LWT- Food Science and Technology, vol. 44, no. 10, pp. 2119-2125, 2011.

[16] Á. Calín-Sánchez, J. J. Martínez, L. Vázquez-Araújo, F. Burló, P. Melgarejo, and Á. A. Carbonell-Barrachina, "Volatile composition and sensory quality of Spanish pomegranates (Punica granatum L.)," Journal of the Science of Food and Agriculture, vol. 91, no. 3, pp. 586-592, 2011.

[17] P. M. N. Ceva-Antunes, H. R. Bizzo, A. S. Silva, C. P. S. Carvalho, and O. A. C. Antunes, "Analysis of volatile composition of siriguela (Spondias purpurea L.) by solid phase microextraction (SPME)," LWT- Food Science and Technology, vol. 39, no. 4, pp. 436-442, 2006.

[18] Á. Calín-Sánchez, A. Figiel, F. Hernández, P. Melgarejo, K. Lech, and Á. A. Carbonell-Barrachina, "Chemical Composition, Antioxidant Capacity, and Sensory Quality of Pomegranate (Punica granatum L.) Arils and Rind as Affected by Drying Method," Food and Bioprocess Technology, vol. 6, no. 7, pp. 16441654, 2013. 
[19] Á. Calín-Sánchez, K. Lech, A. Szumny, A. Figiel, and Á. A. Carbonell-Barrachina, "Volatile composition of sweet basil essential oil (Ocimum basilicum L.) as affected by drying method," Food Research International, vol. 48, no. 1, pp. 217-225, 2012.

[20] SAFC, Ingredients catalago: Flavors \& fragrances, SigmaAldrich, Madrid, Spain, 2015.

[21] Company TGS, The Good Scents Company Information System, 2015, http://www.thegoodscentscompany.com/.

[22] A. M. El-Sayed, Database of pheromones and semiochemicals, The Pherobase, Ed., 2016, Accessed: http://www.pherobase.com/. 


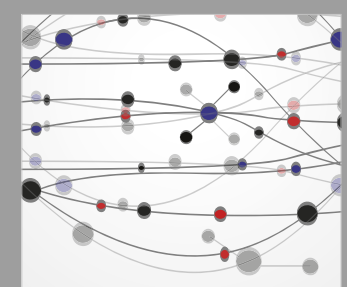

The Scientific World Journal
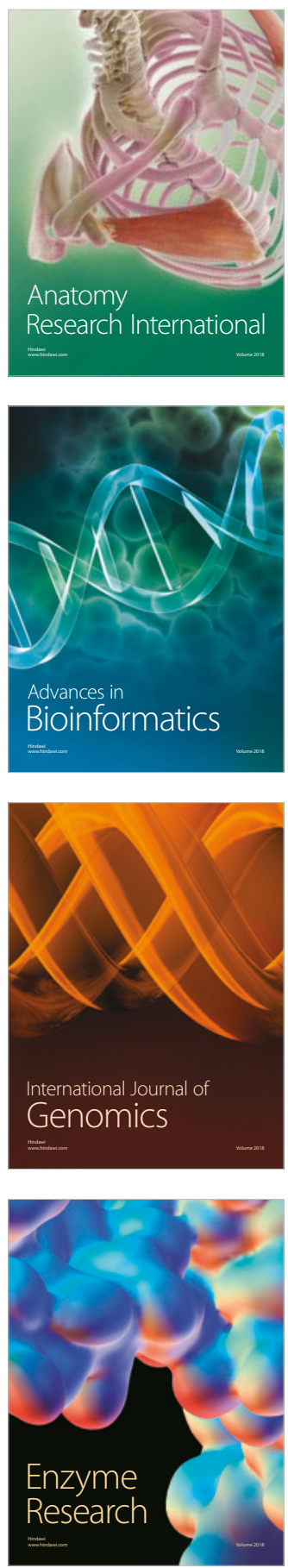
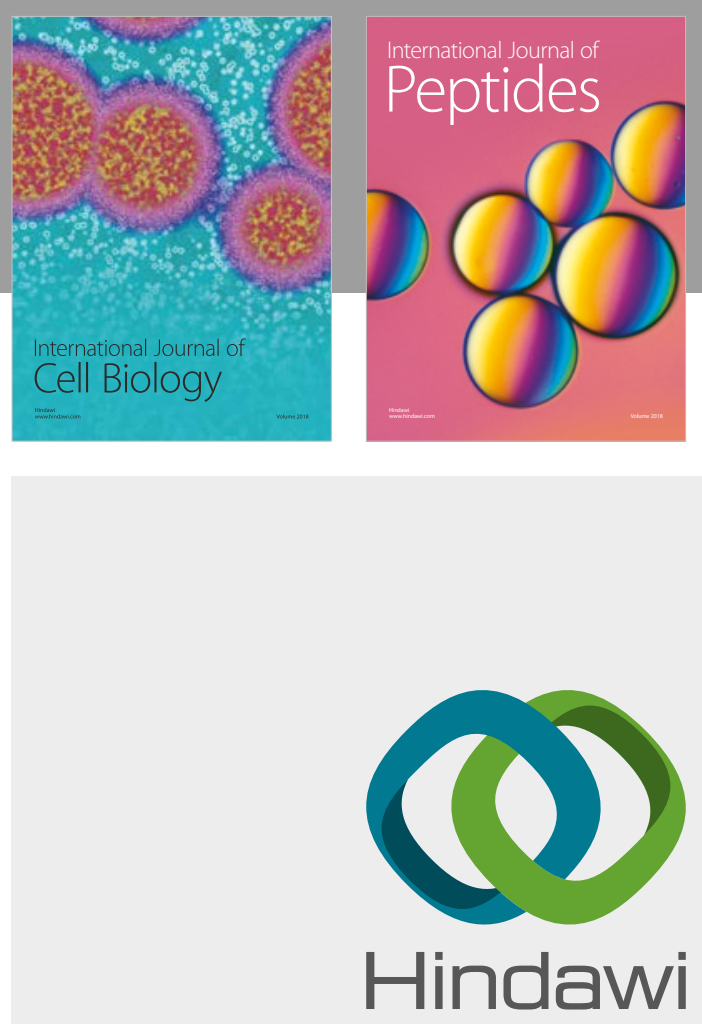

Submit your manuscripts at

www.hindawi.com
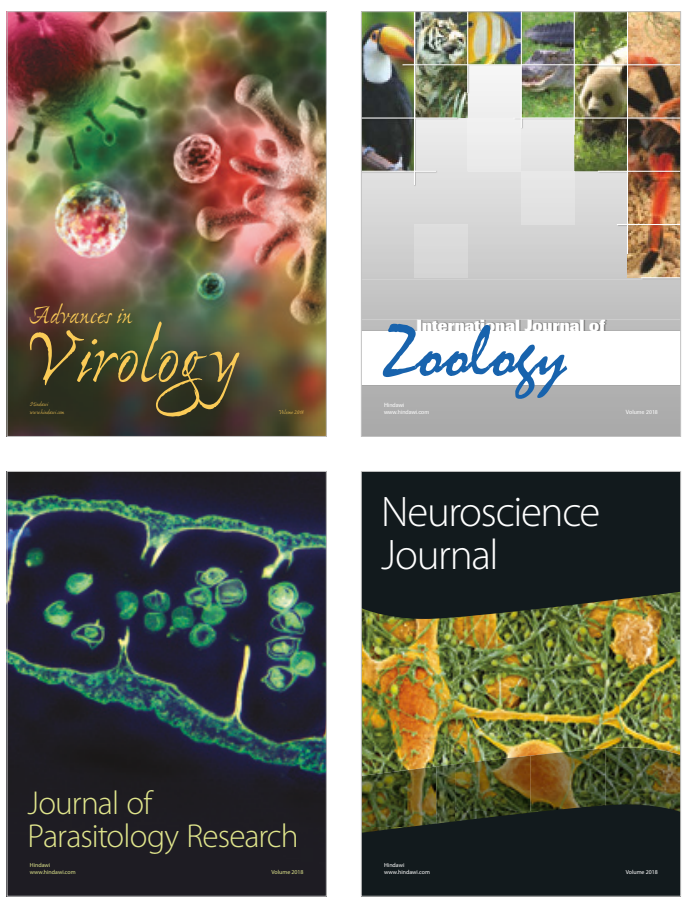
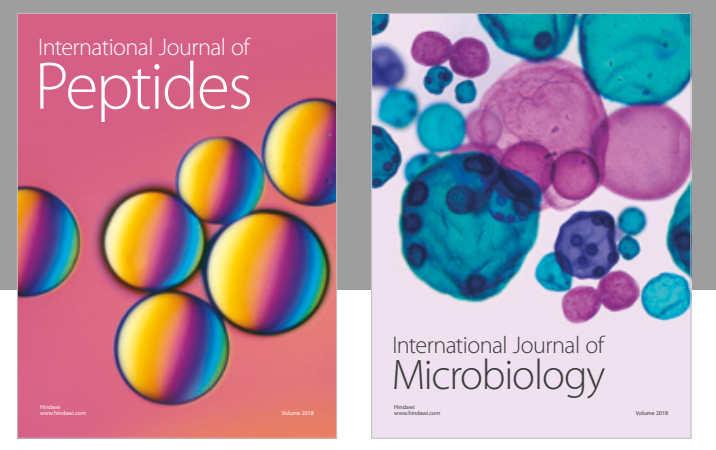

nternational Journal of Microbiology
Journal of
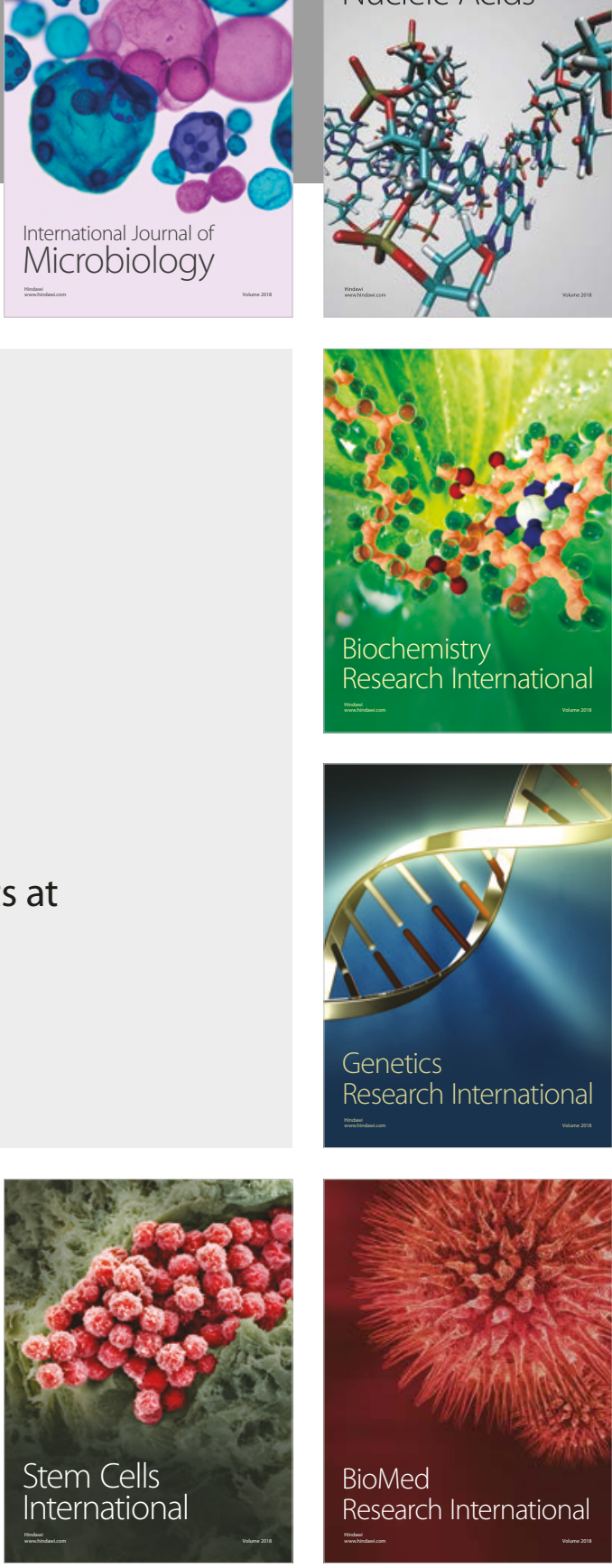
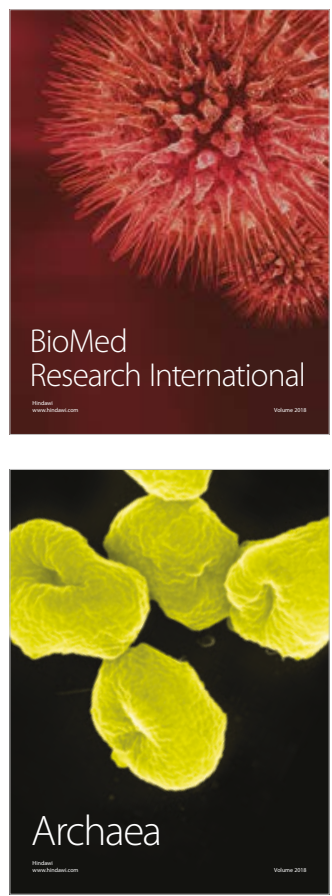